IRA-International Journal of Management \&

Social Sciences

ISSN 2455-2267; Vol.09, Issue 03 (December 2017)

Pg. no. 126-140

Institute of Research Advances

http://research-advances.org/index.php/RAJMSS

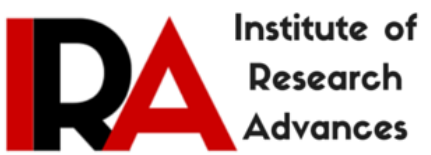

\title{
Causes, Manifestations and Nature of Indigenous Wars in Upper Bakweri Land, 1880-1939
}

\author{
Rose Frii-Manyi Anjoh, $\mathrm{PhD} \&$ Adolf Ngundu Lyonga M.A. \\ Department of History, University of Buea, South West Region, Cameroon.
}

Type of Review: Peer Reviewed.

DOI: http://dx.doi.org/10.21013/jmss.v9.n3.p2

\section{How to cite this paper:}

Anjoh, R.F.M., Lyonga, A.N. (2017). Causes, Manifestations and Nature of Indigenous Wars in Upper Bakweri Land, 1880-1939. IRA-International Journal of Management \& Social Sciences (ISSN 2455-2267), 9(3), 126-140. doi:http://dx.doi.org/10.21013/jmss.v9.n3.p2

(C) Institute of Research Advances.

\section{(cc) BY-NO}

This work is licensed under a Creative Commons Attribution-Non Commercial 4.0 International License subject to proper citation to the publication source of the work.

Disclaimer: The scholarly papers as reviewed and published by the Institute of Research Advances (IRA) are the views and opinions of their respective authors and are not the views or opinions of the IRA. The IRA disclaims of any harm or loss caused due to the published content to any party.

Institute of Research Advances is an institutional publisher member of Publishers Inter Linking Association Inc. (PILA-CrossRef), USA. The institute is an institutional signatory to the Budapest Open Access Initiative, Hungary advocating the open access of scientific and scholarly knowledge. The Institute is a registered content provider under Open Access Initiative Protocol for Metadata Harvesting (OAI-PMH).

The journal is indexed \& included in WorldCat Discovery Service (USA), CrossRef Metadata Search (USA), WorldCat (USA), OCLC (USA), Open J-Gate (India), EZB (Germany) Scilit (Switzerland), Airiti (China), Bielefeld Academic Search Engine (BASE) of Bielefeld University, Germany, PKP Index of Simon Fraser University, Canada. 


\begin{abstract}
The pursuit to control the villages of Upper Bakweri Land (UBL) by the villages of Soppo Mokongo (Great Soppo) and Gbea (Buea Town) led to a series of wars which erupted in the area between 1880 and 1939. The desire for domination resulted to the formation of two main groups which aligned the other villages of UBL under the leadership of either Soppo Mokongo or Gbea. The creation of competing blocs culminated to the upsurge of indigenous wars among the villages of UBL that dragged the two lead villages to support one side or the other. This paper examines the reasons for, the manifestation and the nature of indigenous wars in UBL between 1880 and 1939. To attain the goals of the paper, the chronological and thematic methods were employed in analyzing and synthesizing data obtained from primary and secondary sources. Information from primary sources came from the National Archives Buea $(N A B)$ and oral interviews. Material gotten from secondary sources was from both published and unpublished works. The findings show that political, economic and socio-cultural factors were the driving force behind indigenous wars in the area. That ritualized combat, the cutting of the head of the leader illustrated the nature of warfare. That the weapons of war used were dane guns, cutlasses and clubs. Although, the wars were classified as either "just" or "unjust'; they never succeeded in establishing a lead village in UBL.
\end{abstract}

Key Words: Indigenous Wars, Upper Bakweri Land, Soppo Mokongo, Gbea and alliances.

\title{
Introduction
}

Wars were fought in Upper Bakweri Land (UBL) like in many traditional African societies. ${ }^{1}$ War.is the state of extreme hostility between groups which is aimed at a desired political end. It is an act of violence by a group or groups to compel another to do its will or their will. It involves the use of force to resolve issue(s) beyond diplomatic solution and affirms the Clausewitz Doctrine that "war is the continuation of policy by other means". It was recognized by international law, formalized and some legitimacy is conferred on it. A war even when undeclared usually ends by an agreement, formal or informal, between the belligerents to make peace or at least observe an armistice. It rarely ends through the belligerents' exhaustion or inertia. ${ }^{2}$ The causes of wars could broadly be classified into three groups: political, economic and socio-cultural. One or all of these factors were responsible for indigenous wars that developed amongst the villages of UBL especially as the villages of Soppo Mokongo and Gbea were struggling to gain the leadership position of the entire group. This produced disagreements that led to tensions and suspicion between Soppo Mokongo and Gbea. In other situations, rivalries that involved other villages led to the creation of satellite states by either Soppo Mokongo or Gbea although none of the traditional ruler became powerful enough to exert total control and domination over other societies. ${ }^{3}$ The political, economic and sociocultural factors heightened tensions (mofungu) between the villages and in many cases degenerated into wars (njuma).

Basically, there were two types of wars fought in UBL. These were considered by some informants as 'just' and 'unjust' wars'. ${ }^{4}$ Just wars were those which arose as a result of a village retaliating to an act perpetuated by an aggressor. The 1880s Soppo Wonganga and Soppo Woteke attack on Soppo Likoko, the 1890 Boando war with Molende, the 1890 Gbea attack on Maumu, the 1891-94 Bokwaongo attack on Mapanja, the 1897-1900 Soppo

${ }^{1}$ See Robert S. Smith, "Warfare and Diplomacy in Pre-Colonial West Africa: Studies in African History, London: Methuen \& Co. Ltd.: 1976.

${ }^{2}$ Akachi Odoememe, "Warfare and Diplomacy in Pre-Colonial West Africa" in Perspectives in African History, Edited by Ogbogbo, C.B.N., Ibadan: Bookwright Publishers: 2011.

${ }^{3}$ Interview with John Njanjo Luma, traditional griot and member of the Great Soppo Traditional Council. Great Soppo, 7 August 2016, 45 years Old. He interviewed late Tata Carl Jackai Bender Kange of Soppo Mokongo who died in 2014 aged 95; late Tata Frank Mani ma Toni of Bokwaongo who died aged 90; late Tata Mbwange Eko of Gbea died aged 86 amongst others.

${ }^{4}$ Interview with Luma; Interview with Dan Lyonga. Matute, Senator for Limbe, Bobende-Limbe, 7 June 2016, 63 years Old; Churhill Ewumbua. Monono, Elite of Great Soppo, Great Soppo, 10 July 2016, 56 years Old. 
Mokongo war with Molyko, the 1898-1900 Bokwai attack on Wonya Meyo, and the 1930 Soppo Mokongo attack on Bokwaongo were all considered as 'just wars. ${ }^{5}$ Meanwhile, the 'unjust wars' were those which arose as consequence of attempts to territorial conquest of the village. Thus, the expansionary wars of the warior of Gbea village, Motinda mw'Ekpa of the 1880s, the 1884-85 Soppo Wonganga attack on Mapanja, the 1889 Bonakanda attack on Bova, the 1890 war between Bova and Wonjia, the Bonakanda invasion of Maumu in 1891, and the 1930 Soppo Mokongo attack on Wotolo were all considered as 'unjust wars or conflicts' as they were aimed at fostering the fame and prestige of the aggressor villages. ${ }^{6}$ Whatever the case, the causes of the wars in UBL were as diverse as the manifestation and the nature and calls for adequate examination, which is the focus of this paper.

\section{Prelude}

The Bakweri ethnic group is broadly divided into the Upper and Lower Bakweri. The Lower Bakweri includes the Bimbia, the Ewota, and the Bomboko of the West Coast who are found in Bota, Mokodange, Bobende, Batoke, Sanje and Bakingili as well as East of Tiko and Mondoni. Although, Limbe, which was formerly, called Victoria, is found in the area referred to as Lower Bakweri, it was not considered by the Bakweri as part of Lower Bakweri villages. This was so because the Upper Bakweri used the area to send those who were banished from their land as a result of severe crimes. In this way, it was named by the Upper Bakweri as $V o$, meaning 'a far place'. ${ }^{7}$ The Upper Bakweri who formed the bulk of the tribe is found along the foot of Mount Cameroon: from Mapanja in the west to Ekona Lelu in the east. ${ }^{8}$ To be precise, Upper Bakweri Land is situated on the eastern slopes of Mount Cameroon between latitudes $4^{0} 7^{1}$ and $4^{0} 10^{1}$ North of the Equator and longitude $9^{0} 13^{1}$ and $9^{0} 19^{1}$ East of the Greenwich Meridian. ${ }^{9}$

It is bounded by towns such as Muyuka to the north east, Mutengene to the east and Limbe (formerly Victoria) to the south. It is further located in the South West Region of Cameroon, which shares boundaries to the north with Meme Division and to the west by the Mungo Division of the Littoral Region. UBL is made up of all the villages in the present day Buea Sub-Division which include; Gbea, Bokwaongo, Soppo Mokongo, Soppo Wonganga, Soppo Wovila, Soppo Woteke, Soppo Likoko, Wokoko, Bonduma, Molyko, Muea, Bomaka, Bolifamba, Lysoka, Maumu, Wokeka, Wonganjo, Wonjia, Wonya Meyo, Bonakanda , Bokova, Bokwai, Bova, Ewonda, Bwassa, Likombe, Mevio, Bulu, Sazenhoff, Wotutu, Bonjongo, Boando, and Mapanja, Ewonji. Upper Bakweri territory covers a total area of approximately $50 \mathrm{~km} 2$; about 20 percent of this total surface was later occupied by the colonial plantations in Molyko, Sazenhoff, Upper and Lower Farms, Muea and Ekona. ${ }^{10}$ The scattered nature of the Upper Bakweri settlements can be attributed partly to the difficult terrain that obtains at the foot of Mount Cameroon and partly to the rapidity with which villages were splitting at the time. Map 1 locates Upper Bakweri Land in Fako Division and Map 2 depicts the different villages in Upper Bakweri Land.

The Upper Bakweri constitutes one of the most important Bantu ethnic groups in Cameroon. ${ }^{11}$ They were amongst the first groups to come in contact and had political, economic and social interactions with the Europeans in Cameroon. The history of their migration is explained by myths and legends which give different but complementary views on the origin of the Bakweri. Three schools of thought have developed to explain the origin of the Upper Bakweri. The Soppo School led by Paul Esaso Wolete contends that they are part of the coastal Bantu

${ }^{5}$ Interview with Matute; Interview with Monono.

${ }^{6}$ Interview with His Royal Highness Etina. Monono, Chief of Great Soppo, Great Soppo, 16 July 2016, 61 years Old; Interview with Charles Efungani. Endeley, Son and Confidant of the late Nakuve S.M.L. Endeley and the Crowned Prince of Buea, Buea Town, 31 August 2016, 63 years Old.

${ }^{7}$ Interview with Ferdinand Manga Ewome. Notable and retired Administrator, Bokova, 31 August 2016, 82 years Old. Many of the oral sources interviewed hold that marriages between Upper Bakweri men and women and inhabitants of $V o$ were prohibited because of the severity of the crimes those who were banished had committed. An example of such was murder. This holds true in some cases today.

${ }^{8}$ Mbake, "Traditional Authorities among the Bakweri: A Historical Survey from Pre-colonial Times." D.E.S Dissertation, University of Yaoundé, 1975, 13.

${ }^{9}$ Cletus Forba Fru, "Urbanisation in Buea: Process and Problems (1960-1999)" M.Sc. Thesis, University of Buea, 2004, 2.

${ }^{10}$ Cletus Forba Fru, "Urbanisation in Buea: Process and Problems (1960-1999)" M.Sc. Thesis, University of Buea, 2004, 2.

${ }^{11}$ Mbake, "Traditional Authority among the Bakweri”, 1. 
known as the Kpe-Mboko group who emigrated with the rest of the Bantu race from the Great Lakes region between River Nile and the Congo about 400BC. ${ }^{12}$ From the Congo, these people moved to Bule (around Ebolowa, in the South of Cameroon) where they migrated to a location around Kwakwa River. ${ }^{13}$ They lived there for many years and moved to Baanko. At Baanko disagreement emerged and resulted in a split which led to the emergence of ethnic groups such as Duala, the Balondo and Bakweri under Mukule. Their next migration involved movements through the creeks and forests. Mukule took ill and died on the way and the leadership of the group passed to Elondo and late Mukule's son Soppo. There was another break-up of the group upon their arrival in Ambas Bay. Elondo moved westward along the coast with his group to what is now known as Ndian Division; the Balondo's are Elondo's descendants. ${ }^{14}$

\section{Map 1: Location of Upper Bakweri in Fako Division}

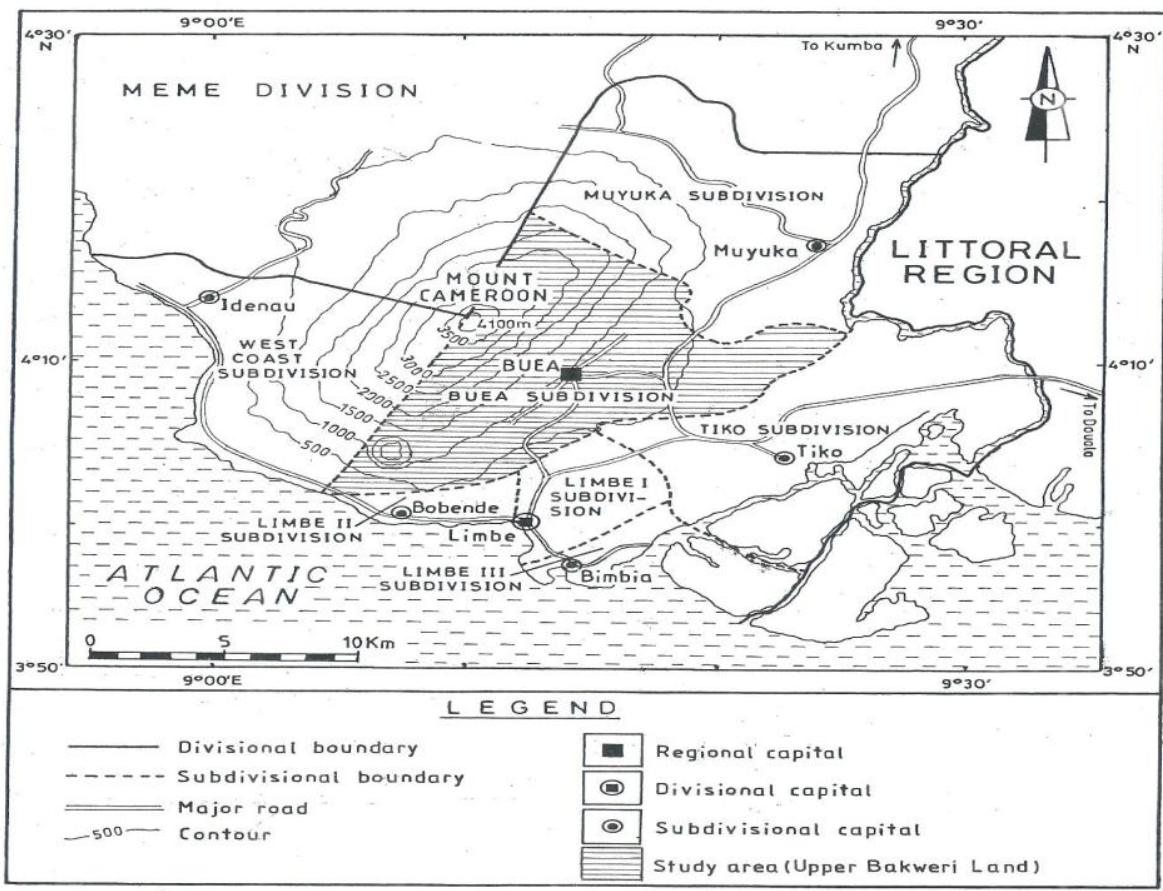

SOURCE: Adapted from the Administrative Map of Cameroon (1999), I.N.C, Yaounde.

Source: Adapted from the Administrative map of Cameroon (1999), N.I.C, Yaoundé.

${ }^{12}$ Churchill Ewumbue Monono, Buea, Capital of the Cameroons: Symbol of the Nation and of Reunification (Buea: CEREDDA, 2015), 1.

${ }^{13}$ Ibid.

${ }^{14}$ Monono, Buea, Capital of the Cameroons. 


\section{Map2: Locating the Different Villages Upper Bakweri Land}

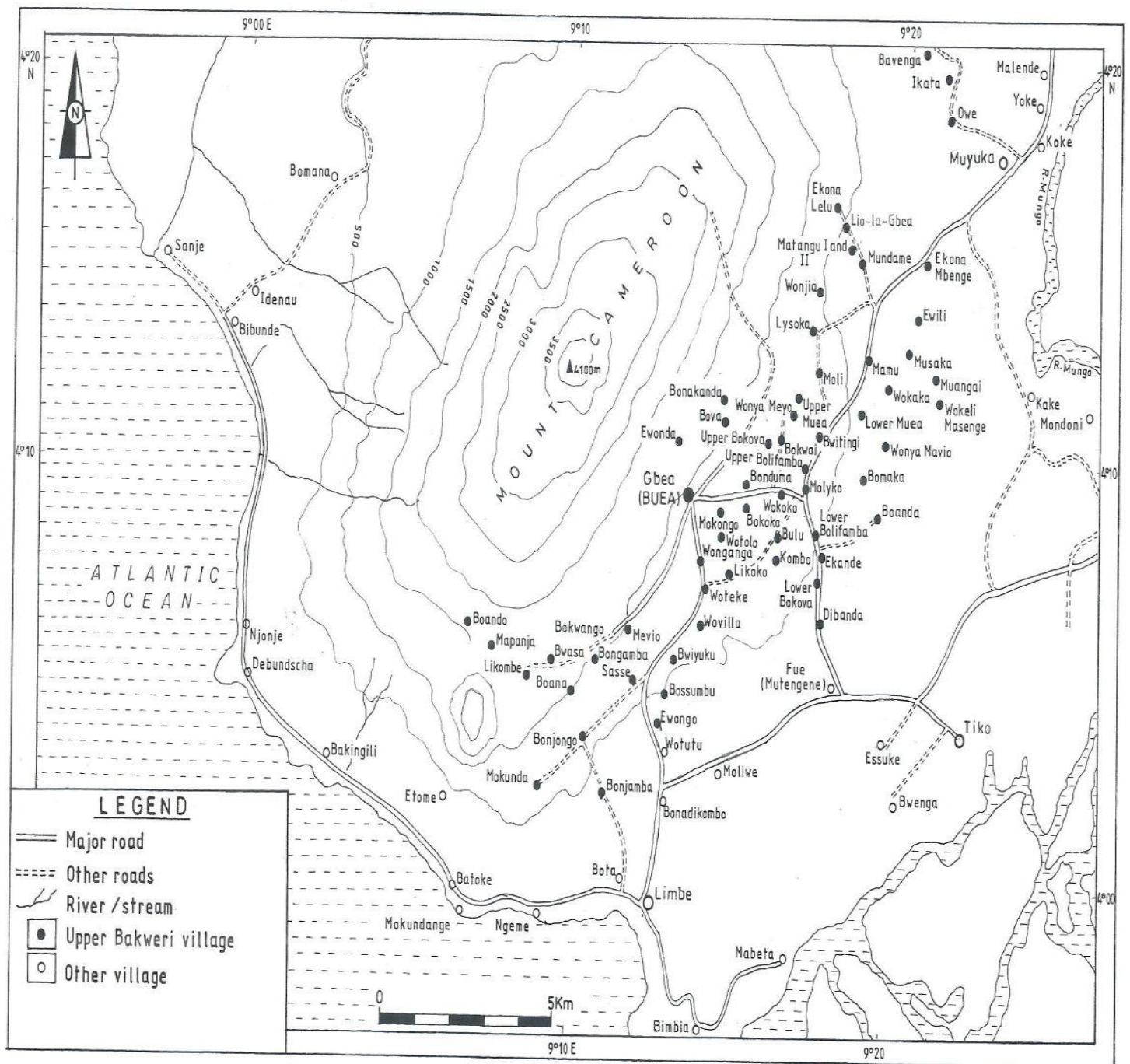

Source: Adapted from the Map of Buea, 1979.

Soppo moved upwards to the foot of Mount Cameroon because he felt that it was better to move away from the coast where the chances of disturbance and interference were always present. Thus, he and his followers erected settlements in Bwassa, Likombe and Membea when they arrived the foot of Mount Cameroon. Besides Soppo, Mukule had several sons who began to move away from Soppo to found new settlements that today make up the 
villages of the Bakweri people. ${ }^{15}$ The Soppo School is based on oral history gathered in the 1920s and 1930s by Esaso Wolete who was the lead Soppo traditional historian as elaborated by Churchill Monono. ${ }^{16}$

According to the Soppo School, Upper Bakweri Land (Buea Country) was founded by the children and descendants of Mokule, who were Soppo, Njoh, Meove, Effeme, Kuh, Manjanga and Mokake. Mokake had three sons; Teke, Molua and Kwaonge who are believed to have settled in present day Buea central originally called kwakwa. The area stretched from the Moli mo Woteke (Signal Hill) in the west, to the Moli mw'Ewongo (the hill behind Opportunity Industrialization Center) in the east. Teke Mokake settled and occupied the area between the moli mo Woteke and the Namonge strean around Monagai's quarter. His nephew Nganga Molue settled between the Namonge and the old Government Station which later became known as the Musole or Gbea settlement. Molua Majanga and his sons established the settlements in Soppo Mokongo, Soppo Wonganga and Soppo Wovilla villages. The descendants of Kwaongo Mokake are said to have settled in Soppo Wonyakwaongo and Wondongo, still others founded Bwenga wo Manjanga and the moli mo Liwenje (From the stadium in Gbea to Vasingi). ${ }^{17}$

However, the Upper Buea School points to a certain Mokuri as being the ancestor of the Bakweri people. ${ }^{18}$ Mokuri is said to have migrated to Buea from Kwakwa, a tributary of the Sanaga. Mokuri moved about the same time that his uncle Kole Mbedi left Piti on the Dibamba River and moved to found the Bakole and Bamusso ethnic groups. After moving through the creeks, he arrived at Bimbia from where he moved inland and founded two settlements on the slopes of Mount Cameroon named after his original location Kwakwa and Vokoso. These settlements were situated around the present-day Lower Farms and include Old and New Clerk's Quarters in Buea..

Mokuri's son, Soppo, had a son called Manjanga who also had two sons called Mokako Manjanga and Moki Manjanga. Mokako Manjanga had three sons namely Kuwamongo, Teke and Molua. They founded the settlements of Mosole (later to be known as Gbea), Soppo Mokongo, Soppo Woteke, Soppo Wonganga and Soppo Wovila respectively. ${ }^{19}$ Naliomo/Nabongo had two sons namely Wuma and Eya. Nothing is heard of Wuma after this, but Eya had three sons called Nyawe, Vefonge and Mokomba. Vefonge had Lyonga la Vefonge who in turn became the father of Likenye Lyonga, father of Kuva Likenye and Endeley Likenye. ${ }^{20}$

The original settlers of Upper Bakweri Land are the Bakweri. They are believed to have migrated from Womboko (Bomboko) before occupying their present site. This ethnic group is composed of a total of 106 villages ${ }^{21}$ which covers an approximate surface area of $1024 \mathrm{~km} 2$; from the bight of Biafra in the South to the foot of Mount Cameroon. It extends to Bakolle in the North and West and to the banks of the River Mungo in the East. ${ }^{22}$ In the absence of any accurate recorded history, one cannot be certain at what date the Bakweri reached their present site. Edwin Ardener dates the settlement of the Bakweri around 1750 or $1770 .^{23}$

The Wonya Ewunga School of thought holds that Eya Njie Tama Lifanje, who migrated from Womboko, founded Gbea which later became Buea. ${ }^{24}$ Eya, who usually came from Womboko hunted on the eastward side of the mountain with a friend called Nakande. Nakande hunted near the site of present Bonakanda while Eya move on

${ }^{15}$ Matute, The Socio-Cultural Legacies of the Bakweri, 9.

${ }^{16}$ Monono, Buea, Capital of the Cameroons, 1-2.

${ }^{17}$ Interview with Hon P.R.L. Ikundi, Former Municipal Administrator of Buea Rural Council/Former MP for Fako, Buea Town, 21 August 2016, 73 years Old. This information was also stated in Monono, Buea Capital of the Cameroons, 2.

${ }^{18}$ Interviews with Prince Charles Efungani Endeley, Retired Senior Administrator with the CDC, Buea Town, 63 years Old, 31 August 2016. He was the son and confidant of the late Nakuve S.M.L. Endeley; Interview with Manga Ewome.

${ }^{19}$ Interviews with Prince Charles Efungani Endeley; Interview with Manga Ferdinand Ewome.Notable and retired Administrator, Bokova, 31 August 2016, 82 years Old.

${ }^{20}$ Edwin Ardener, Coastal Bantu of the Cameroons: An Ethnographic Survey of Africa (London: International African Institute, 1956), 14-17.

${ }^{21}$ Ibid.

${ }^{22}$ Mbake, "Traditional Authority among the Bakweri”, 24.

${ }^{23}$ Ardener, Coastal Bantu of the Cameroons, 16.

${ }^{24}$ Mbake, "Traditional Authority among the Bakweri”, 24. 
to the Musole stream near present-day Gbea. He built a shelter where he slept and smoked the animals he killed which he carried to Womboko after a few days and was always meeting his friend Nakande on the way. ${ }^{25}$ They later brought their wives and children who cultivated gardens. They constantly referred to their hunting site as " $O$ ligbea" ${ }^{26}$ and their successful exploit made them to rejoice and said "Na ma gbea." ${ }^{27}$ The constant hunting expedition of Lifanje finally led to the settlement at the foot of Mount Gbea, today known as Mount Fako or Mount Cameroon ${ }^{28}$ It is important to note that all the three versions of the migratory history of the Upper Bakweri People are linked to Soppo and his off- springs.

The founding of new villages, Mboa, among the Bakweri appears to have been accomplished by individuals and not by groups. A son or several sons or just any adult male left the settlement of his father and moved away to found a new one. These movements occurred when new hunting grounds were discovered. In one case a son who left his father's hut later brought his wife or wives and children with him to start a village. At another time, an individual may decide to move away from an existing village to found another if he felt he was in the midst of hostile neighbours. Still at other times, some people left their villages and settled in isolated spots to ensure that their wives were not seduced and taken away by younger or stronger men. ${ }^{29}$ Such people were joined by others and with time, villages grew out of these settlements. Such villages were, more often than not, named after their founders who became leaders in most cases. ${ }^{30}$

Each village was independently controlled by the village head, a council of Elders and supported by juju societies all operating under the guidance of established norms. ${ }^{31}$ The pre-colonial political organization of the Upper Bakweri people falls in line with other related ethnic groups like the Duala and Bakossi. The basic political unit among the Bakweri was the village. ${ }^{32}$ The political system was decentralized before the coming of Europeans and was based on a democratic village government. It comprised of selected members of the founding families that made up the village council, where the sang'a mboa was the head of the village community with coercive power. By this system, each village was ruled by a council of elders called walulu wa mboawho with representatives of the main lineages, and the sang'a mboa at the head. At the level of the extended family, the movo'o mo litumba (family head), directed the economic life of the group. At the beginning of each planting season, he allocated land to his wives, to those of his brothers and sons as well as to the unmarried or divorced sisters and daughters who had come back and were reconsidered as members of the lineage. The sang'a mboa and the wambaki wa mboa (council of elders) represented the people and acted as the executive and judiciary arm of the village. ${ }^{33}$ The wambaki wa mboa were also responsible for confirming and coronating a new village head in case of any vacancy of the throne.

The government of the village was in the hands of a college of elders who were often heads of the various lineages, the walulu wa litumba. It sometimes included individuals with distinct qualities such as elders who distinguished themselves in wars, successful hunters and wealthy men like Moma Mbella and Esaso Wolete of Soppo Mokongo and Motinda mw'Ekpa and Mondind'a Lyonge of Gbea. The college of elders advised the village council on the affairs of the village and conducted diplomatic relations where necessary. The general administrative duties of the village council involved settling disputes between villagers, arranging for the cleaning and clearing of the village and bush paths, the erection or repair of fences around the village and discussing matters which concerned the welfare of the community. ${ }^{34}$

${ }^{25}$ Ardener, Coastal Bantu of the Cameroons, 11.

26 "O lib bea" literally means "I am from doing it."

27 "Na ma ubea" meaning "I have done it."

${ }^{28}$ Matute, How did Buea Orignate?, 5.

${ }^{29}$ NAB, Ag.10. File No. EP.11372A. W.M Bridges D.O's Intelligence Report on Bakweri of Victoria Division, Cameroon Province.

${ }^{30}$ Mbake, "Traditional Authority among the Bakweri", 13; See also Edwin Ardener, Kingdom on Mount Cameroon: Studies in the History of the Cameroon Coast, 1500-1970 (Oxford: Berghahn Books, 1996), 51.

${ }^{31}$ Mbake, "Traditional Authority among the Bakweri”, 30-33.

${ }^{32}$ Ibid., 34-35.

${ }^{33}$ Ibid. 36.

${ }^{34}$ NAB, Ag.10. File No.EP.11372A. 
Sometimes, decisions were taken by the entire village community. The people were called together by jimbi (a talking drum) to discuss matters that concerned them or to discuss new regulations. After the assembly had approved the proposals, a new proclamation was sent round by the mote'e esewa (village crier) and the law came into force. ${ }^{35}$ This was, in other words, a traditional democracy resembling in some aspects, the government of the Greek city state where popular assemblies composed of all male citizens, made major decisions and laws. There was not only the existence of a law-making body but a judiciary that adjudicated the laws.

The traditional judiciary was of two categories. At the bottom of the lineage was a judicial unit called the lilyaili we litumba and above it, there was the wambakiwa mboa (council of elders) which formed the judicial arm of the traditional government. Disputes between members of an extended family were resolved by the lineage head movo mo litumba while disputes involving different families were resolved by the village council. In the case of the former, the head of the lineage summoned his relatives who heard both sides of the matter and gave a verdict. In the latter, the council of the village was summoned by the village head and only the members acted as the judges, but anybody who felt like attending the session could do so. ${ }^{36}$

In addition to that, the entire village would be present and villagers who were not members could be asked for their opinions depending on the severity of an offence. Examples of such offences included murder and certain insults especially directed towards women. The serious offences such as murder, witchcraft and the refusal to repair one's portion of the village fence attracted heavy penalties. The introduction of colonial rule led to the creation of the appellation chief and strengthening of the institution in the villages of Upper Bakweri Land. It also led to the establishment of a lead chief or a paramount chief whose authority was intended to be widely recognized in his area of jurisdiction. The coming of colonialism ushered in two powerful families in the area, namely the Wonya Likenya Endeley of Gbea and the Ewumbue Fike of Soppo Mokongo. Before colonization, though these families were at the head of their respective villages, their powers as rulers were limited to their immediate area of jurisdiction and did not extend to other villages. ${ }^{37}$ Although, there was a well delineated indigenous political structure to ensure peace and cohesion in each village several factors led to wars and their manifestation between the villages as examined below.

\section{Causes and Manifestations of Wars in UBL}

There were political, economic and socio-cultural reasons expounded to explain the occurrence of wars in UBL. The political reasons responsible for wars in UBL included prestige, acquisition of strategic areas and the desire to expand the village territorially. Between 1883 and 1890, the 'Great Warrior of Gbea,' Motinda Mwe Ekwa engaged in the wars of promoting the prestige and influence of Gbea by instigating and conquering various Upper Bakweri villages to bring them under the control of Gbea. These wars which were christened "the Wars of expansion of Motinda Mwe Ekwa", brought Bova, Bonakanda, Bokova, Bwitingi, Bokwai, Molyko, Ekona, Likombe, Bwasa and Bokwaongo under the control of Gbea. ${ }^{38}$

According to many oral sources, Motinda who was greatly feared by the warriors of these villages used the element of surprise and cultic or spiritual powers to bring these villages under the influence of Gbea.

Motinda's desire to extend the influence of Gbea was only halted in 1889 when he attacked Woteke and was met with stiff resistance from the warriors of Soppo Mokongo ${ }^{39}$ who came to the assistance of Woteke claiming that Woteke was founded by Teke Molua, one of the sons of Molua Mokako, the founder of Soppo Mokongo. Again, Soppo Mokongo also wanted to check the spread of the influence of Gbea. ${ }^{40}$ Motinda and his warriors from Gbea were defeated and they had to retreat. This ended the expansion of Gbea but led to the rise of tensions between Soppo Mokongo and Gbea.

Between 1890 and 1891, conflict developed between Bonakanda (a Gbea satellite village) and Wonjia. The people of Bonakanda under their leader Teke Nakande claimed that Wonjia was part of Bonakanda and that it was

${ }^{35}$ Ibid

${ }^{36}$ Mbake, "Traditional Authorities among the Bakweri", 37.

${ }^{37}$ Ardener, Kingdom on Mount Cameroon, 46.

${ }^{38}$ Interview with P.R.L. Ikundi; Interview with Charles E. Endeley.

${ }^{39}$ Interview with John Njanjo Luma.

${ }^{40}$ Interview with HRH Chief Etina Monono, Chief of Great Soppo, Great Soppo Palace, 16 July 2016, 61 years Old. 
used by their ancestors and them for farming and hunting before Njia Nakande, one of the sons of Nakande (founder of Bonakanda) first settled there. ${ }^{41}$ The Wonjia people refuted and challenged this claiming that Wonjia was an independent village from Bonakanda though founded by Njia Nakande. Without any warning and with the encouragement of Gbea, Teke Nakande and his warriors attacked and took control of Wonjia. The war was swift as a result of the large number of warriors from Bonakanda. Wonjia, with its little population and ill-preparedness, had no chance against the well prepared Bonakanda warriors. At the end, Wonjia was defeated and sources hold that some Gbea warriors aided Bonakanda in this conflict. As compensation, Wonjia had to give twenty goats, fifteen pigs and foodstuff to Bonakanda as indemnity. ${ }^{42}$ Thus indirectly, Gbea extended its influence to Wonjia.

In 1897, a few years after the Gbea-German War of 1891-1894, Soppo Mokongo took advantage of the weakness of Gbea and attacked Molyko which was under the influence of Gbea. The main cause of the war was that Molyko under its leader Mbake Joke had laid claim over the control of Bulu. However, the leader of Bulu, Molua mo Njoni, had expressed his willingness to be under Soppo Mokongo. Chief Mwanja of Soppo Mokongo asked Molyko to renounce their claim to Bulu, but Chief Joke of Molyko, purportedly with encouragement from Gbea, refused. The Soppo Mokongo warriors, angered by this Gbea interference attacked Molyko, conquered it, and demanded the payment of compensation and the renunciation of claims to Bulu. ${ }^{43}$ Molyko capitulated and on the invitation of Chief Mbake Joke peace was brokered by Chief Woloa Naowa of Wokulu. The outcome of the 1889 intervention by Soppo Mokongo to check the Gbea expansion into their backyard and the Soppo defeat of Molyko, a Gbea satellite village, increased the prestige and influence of Soppo Mokongo and heightened tensions with Gbea. ${ }^{44}$

Another war which was caused by prestige and the desire to extend authority occurred in 1930 between Soppo Mokongo and Wotolo. Chief August Monono of Soppo Mokongo in a bid to show his prowess, increase his authority and extend his Chiefdom; ordered the occupation of Wotolo by Mokongo Warriors. Under the leadership of Ekema Wokuve, Mokongo Warriors attacked Wotolo in 1930 and occupied it. It is alleged that the main reason why August Monono attacked Wotolo was to divert attention from the fiscal challenges he had and the diminishing of his authority in UBL. Some sources hold that he also wanted to extend his territorial space just as Gbea had been doing. ${ }^{45}$ Whatever the reasons, Mokongo attacked Wotolo, but Bonakanda Warriors with the backing of some Gbea warriors, came to the assistance of Wotolo on the pretext that Wotolo was founded by Tolo Nakande, one of the sons of Nakande the founder of Bonakanda.

Though Soppo Mokongo won the war, the British Administration headed by the District Officer of Buea, W.M. Bridges intervened and put an end to the conflict. The British intervention was because they did not want Wotolo to come under the influence of Soppo Mokongo which already had ten villages under its auspices. These villages included Wonganga, Woteke, Wovila, Kombo, Wulu (Bulu), Wolikova, Wonganjo, Wotuke, Wokeli (Satzenhoff), and Likoko Langoso. ${ }^{46}$ The British intervention also showed that they were prepared to check and control the influence of Soppo Mokongo which had played a dominant role during the German administration of Buea, 1891-1916. ${ }^{47}$ As important as political factors were in contributing to war in the area, economic concerns could not be overlooked.

41 Interview with Ewoma Molombe, Notable, Bonakanda, 22 June 2016, 83years Old; Interview with Mwambo Paul Ewome; Interview with Njie Mosoke Ewome, King Maker of Wokulu, Molyko, 30 April 2016,83 years Old.

${ }^{42}$ Interview with Ewoma Molombe.

${ }^{43}$ Interview with John Njanjo; Interview with Matanga Monono, Member of the Great Soppo Royal Family and Traditional Council, 19 June 2016, 55 years Old, Interview with Smith Molua Becke, Notable, Great Soppo, 6 July 2016, 76 years Old.

${ }^{44}$ Interview withJohn Njanjo; Interview with Matanga Monono; Interview with Smith Molua Becke.

45 Interview with John Njanjo; Interview with Rebecca Motomby Becke, Leader of the Great Soppo Women, Great Soppo, 6 July 2016, 65 years Old; Interview with Samuel Ikome, Notable, Great Soppo, 17 May 2016, 63 years Old.

${ }^{46}$ Interview with John Njanjo.

${ }^{47}$ Interview with HRH Chief Etina Monono; Interview with Isaac Efange, Notable, Wonganga, 17 May16, 83 years old. 
Economic conflicts between villages in UBL that produced wars were instigated by the competition to control farmlands, hunting grounds, natural resources and slaves. ${ }^{48}$ In about 1882, Soppo Wonganga and Soppo Woteke launched an attack on Soppo Likoko claiming it as their ancestral farmland. According to oral sources, a stranger Ngoso Nganele (a hunter from Gbea) was attracted to settle in Soppo Likoko because of the wide variety of animals found there. Ngoso became arrogant, rude and did not respect the people of Soppo Wonganga and Woteke. ${ }^{49}$ Again, it was observed that he did not fulfill the conditions necessary for him to have settled in the area. ${ }^{50}$ Besides, the fact that he came from Gbea was a bitter pill to swallow by these Soppo Mokongo surrogates. Furthermore, Ngoso became a prominent farmer of crops and animals and turned the area into a real agricultural heaven. As a result the people of Wonganga and Woteke were angry and jealous and attacked Likoko. ${ }^{51}$ The war was short-lived and Likoko fell within a few days. Ngoso invited Chief Sako Ewumbua of Soppo Mokongo who brokered peace. Ngoso Nganele had to pay indemnities in the form of three large pigs, five goats and food crops. ${ }^{52}$

Trade was the main cause of the Soppo Wonganga attack on Bimbia in 1883. According to oral sources, Bimbia enjoyed the middleman monopoly position due to their proximity to the coast. ${ }^{53}$ The goods which were exchanged with the Europeans passed through the people of Bimbia. The head of Wonganga, Nganga, also accused the traders of Bimbia of cheating the traders and people of Wonganga by way of high charges on the European commodities. Thus, the warriors of Wonganga in 1883 attacked Bimbia. Sources hold that though Wonganga occupied Bimbia for a few weeks, Nganga secretly called on the Chief of Soppo Mokongo, Sako Ewumbia and King Bell (Ndumb'a Lobe) of Duala of Bell Town to broker peace. Nganga withdrew his warriors and gave a pig (mwambala) to Bimbia. ${ }^{54}$

Between 1884 and 1885, war broke out between Soppo Wonganga and Mapanja. The dispute erupted over ownership of land which the Mapanja people claimed they had been farming on over the years. Wonganga claimed that the disputed piece of land was originally a part of Wonganga and called on the Mapanja village head to renounce all claims. This demand was rejected and Nganga of Wonganga took advantage of the inferiority strength of Mapanja and launched his attack. In the course of the war, warriors from Bonjongo and Boando came to the assistance of Mapanja. This changed the tide of the war and led to the surrendering of Nganga and his warriors. On the invitation of Wonganga, Chief Mwaka mo Woloa of Soppo Mokongo negotiated peace between the factions and Wonganga had to pay compensation to Mapanja and also recognize its right of ownership of the disputed area. The defeat of Wonganga and the negotiations carried out by Mwaka mo Woloa of Mokongo led to the formation of the Soppo Alliance in 1885 between Mokongo, Wonganga, Woteke and Wovila. Amongst other things, they agreed to come to each other's assistance in the event of war. ${ }^{55}$

The refusal by the Maumu people to grant the right to hunt to Gbea was the main cause of the Gbea attack on Maumu in $1890 .^{56}$ The Gbea people under their leader Kuva Likenye and their Chief Warrior-Motinda Mwe Ekpa saw this as a serious challenge to their prowess and prestige and attacked Maumu. Within a very short time, Maumu fell since they could not withstand the superiority of the Gbea warriors. At the end of the war, Gbea forced Maumu to pay compensation, took many young men as captives as well as many young women, animals and foodstuff. It is worthy to point out that sources hold that some of the animals seized from Maumu were used by Gbea as compensation to the Germans after the wars of 1891 to 1894.

Economic reasons also accounted for the war in 1891 between Bonakanda and Maumu. Soon after the Gbea-Maumu war, and while the people of Maumu and their warriors were still trying to recover from the effects of the war, Bonakanda warriors under their leader Teke Nakande attacked Maumu. This war broke out as a result of a disputed portion of land which the people of Bonakanda claimed had been used by their founder Nakande for

${ }^{48}$ Interview with HRH Chief Etina Monono; Interview with Isaac Efange.

${ }^{49}$ Interview with John Njanjo Luma.

${ }^{50}$ Idem.

${ }^{51}$ Interview with Chief Etina Monono; Interview with Isaac Efange.

${ }^{52}$ Interview with Chief Etina Monono; Interview with Isaac Efange

${ }^{53}$ Interview with John Njanjo Luma; Interview with Churchill Monono; Interview with Dan Matute.

${ }^{54}$ Idem.

${ }^{55}$ Interview with John Njanjo Luma; Interview with Churchill Monono, Elite and Author of Bakweri issues, Wonganga, 10 July 2016, 56 years Old.

${ }^{56}$ Memoirs of Carl Jackai Bender Kange, died aged 95. 
farming. ${ }^{57}$ Meanwhile, the search for firewood by Bonakanda women also led to the brawl. It was held that, the land actually belonged to Maumu but the people of Bonakanda had admired its fertility for a long time and took advantage of the fact that Maumu was just coming out of a devastating war with Gbea which left them economically and militarily weak. ${ }^{58}$ The war lasted only for a few days and Maumu surrendered. In addition to seizure of the disputed portion of land, animals, foodstuff and prisoners were taken by Bonakanda as compensation.

The quest for the acquisition of farming ground by Bova also accounted for the hostilities that broke out between them and Wonjia between 1892 and 1893. The people of Bova in addition to practicing hunting were also farmers engaged in the production of cocoyams, yams, plantains and cassava. According to oral sources, in those days, the markets in Muea and Tiko were mainly supplied with these crops produced by farmers from Bova and Bonakanda. ${ }^{59}$ They also hold that Wonjia was easily overrun by Bova but they resorted to the use of mosquitoes (mystical powers) which bit the Bova warriors forcing them to retreat and thus, bringing an end to the invasion. ${ }^{60}$

In the years between 1891 and 1894, ${ }^{61}$ a serious war broke out between Bokwaongo and Mapanja over a piece of land which both villages had been using as hunting ground. Some sources hold that a hunter from Bokwaongo-Evovi had hunted and caught so much game but was attacked by some hunters from Mapanja who beat him up and made away with his catch. ${ }^{62}$ Other sources hold that Mapanja had been using this particular hunting ground for long but Bokwaongo took advantage of the weakness of Mapanja militarily especially after the war with Wonganga which had had a heavy toll on them. ${ }^{63}$ Whatever the reasons, Bokwaongo between 1891 and 1894 attacked Mapanja on a day when they had a traditional ceremony called sassa. The Bokwaongo warriors killed the chief, seized animals and other valuables and forbade the people of Mapanja from using the hunting grounds.

A few days after the departure of the Bokwaongo warriors, the Mapanja warriors with assistance from their allies Boando and Bonjongo attacked Bokwaongo. Sources hold that the war was a bitter one that dragged on for quite some time and culminated to the death of the chief of Bokwaongo and many warriors from both sides. The battle finally ended at a brook near Likombe. This brook was later called wewoni meaning 'bullets.' Peace was brokered by the chief of Soppo-Sako Ewumbua and both sides decided to end the fighting and carry home their wounded and dead warriors. ${ }^{64}$

Disputes over hunting grounds also led to the war between Bokwai and Wonya Weyo. Oral sources consulted placed the war to have happened around 1894 and held that both villages had been using these grounds amicably without any conflicts. ${ }^{65}$ Nevertheless, owing to the fact that Bokwai had been brought under the control of Gbea by Motinda mwe Ekpa and that many of the Bokwai warriors fought in the Motinda mwe Ekpa wars of conquest; and had developed the belligerent attitude; they claimed complete ownership of the disputed hunting grounds and stopped the hunting expeditions of Wonya Weyo on the acclaimed site. The men of Wonya Weyo who were mostly farmers could not abide by this laid down regulation, thus, they continued to use the land for their hunting expeditions. Consequently, the Bokwai warriors attacked and seized control of the land in the same vein brought Weyo under Bakweri supremacy. ${ }^{66}$ Apart from political and economic factors that were paramount in instigating wars in UBL, social considerations also played a significant role in the development of hostilities in the area.

Wars fought on socio-cultural grounds were brought about by defeat during wrestling bouts, allegations of witchcraft and the practice of it during wrestling encounters, forced marriages and differences over women. In 1889,

${ }^{57}$ Interview with Ewoma Molombe; Interview with Mwambo Paul Ewome; Interview with Njie Mosoke.

${ }^{58}$ Interview with Ewoma Molombe; Interview with Njie Mosoke.

${ }^{59}$ Interview with John Monangai mo Evakise, Notable, Bokwaongo, 21 June 2016, 86 years Old.

${ }^{60}$ Idem.

${ }^{61}$ Interview with John Njanjo Luma.

${ }^{62}$ Idem.

${ }^{63}$ Interview with John Monangai mo Evakise.

${ }^{64}$ Interview with Chief Etina Monono; Interview with Sam Efufa Becke, Elder, Great Soppo, 6 May 2016, 86 years Old; Interview with Smith Molua Becke.

${ }^{65}$ Interview with John Monangai mo Evakise.

${ }^{66}$ Interview with Ewoma Molombe; Interview with Mwambo Paul Ewome; Interview with Njie Mosoke. 
Bonakanda invaded Bova as a result of the refusal by Bova for men from Bonakanda to forcefully take young women from Bova for marriage. This had been a practice that had been going on before 1889. The people of Bova hated this because only the most beautiful of their young women were taken and forced into marriage. Again, this had an adverse effect on the population of Bova as there were always fewer women available to the Bova men for marriage ${ }^{67}$ Subsequently, the refusal of Bova men to let the Bonakanda men force their young women into marriage led to an invasion by Bonakanda. Sources consulted purported that the Bonakanda warriors had mystical elements which made them invincible to bullets. The secret was however revealed to the warriors of Bova by Kotto Mbonde whose mother came from Bova, though he resided in Bonakanda as a result of the forceful marriages. He told the Bova warriors to use eggs laid by local birds (fowls) instead of guns to shoot the Bonakanda warriors. That weakened their charms and thereby, led to their defeat, the withdrawal of their warriors and the end of the forced marriage practice. ${ }^{68}$

In 1894 also, Boando went to war against Molende after some Boando wrestlers were killed in Molende following their victory in a wrestling encounter. The Boando wrestlers accused their Molende counterparts of using magical practices which led to their victory. Wrestling was one of the most prestigious activities in UBL which brought fame and prestige to the villages. Following the incident in Molende, Boando warriors were rallied and an attack was launched against Molende. The war which is alleged to have led to many casualties and loss of property was won by Boando. Molende young women and men were taken as captives of war and a heavy compensation in the form of animals and food stuff was inflicted on them. ${ }^{69}$

The outcome and hostilities in a wrestling encounter accounted for the combat between Bokwaongo and Soppo Mokongo in 1930. Bokwaongo was revered by many of the villages of UBL as the champions of wrestling. Their champion (ngumu)-Wana Evulu nicknamed Mazeku Motowa, ${ }^{70}$ because he always shaved his hair and left sit patches of hairs on his head, was greatly feared and famed in UBL. ${ }^{71}$ Oral sources had it that before wrestling bouts, he usually ate raw cocoyams and plantains. ${ }^{72}$ However, in a wrestling encounter hosted by Bokwaongo, Wana Evulu was aptly defeated by David Koffi Kange of Soppo Mokongo. The people of Bokwaongo could not withstand such shame and disgrace on home turf. Thus, they got the Soppo Mokongo wrestlers and supporters well beaten and many suffered grave injuries. ${ }^{73}$ The Chief of Soppo Mokongo-August Monono, angered by this action, summoned his warriors under the leadership of Mome Mbella and Ekema Wokuve to attack Bokwaongo. Houses were burnt and people were wounded. Consequently, the chief of Bokwaongo in response raised the 'White Flag' and sued for peace. Bokwaongo agreed to pay indemnities in the form of animals and food crops. ${ }^{74}$ Therefore, political, economic and socio-cultural factors necessitated the outbreak of wars in UBL. The nature of the wars was as diverse as the causes and manifestations.

\section{The Nature of the wars in UBL}

The fighting of the diverse wars in UBL came in four different dimensions. These included ritualized combats on traditional battle grounds (mafany). This was the case of the Motinda mwe Ekpa wars of expansion of the 1880s and the 1891/94 Bokwaongo-Mapanja war. The second way through which wars were carried out was through ambush. This technique was used by Motinda mwe Ekpa in the 1880s and likewise, Bonakanda used it on Wonjia in the 1890-1900 war. In addition, Bokwai employed it in 1898 in the war with Wonya Meyo. Thirdly, villages of UBL also used the tactic of surprise attacks. In 1884, Soppo Wonganga launched a surprise attack on Mapanja while in 1891, Bova used it on Wonjia, Soppo Likoko and similarly, Bokwaongo used it on Mapanja. In the fourth dimension, there was the outward and total declaration of war on a village. The 1884 war between Soppo Wonganga

${ }^{67}$ Interview with Ewoma Molombe

${ }^{68}$ Interviews with P.R.L. Ikundi; Interview with Smith Molua Becke; Interview with Ekwa Itue Hans, Notable, Great Soppo, 16 May 2016, 91 years Old.

${ }^{69}$ Interview with Ekwa I.H.

${ }^{70}$ Interview with John Monangai mo Evakise; Interview with Mbua Dan Efeme, Member of the Great Soppo Traditional Council, Great Soppo, 20 August 2016, 53 years Old; Interview with Isaac Efange.

${ }^{71}$ Interviews with P.R.L.Ikundi; Interview with Smith Molua Becke.

${ }^{72}$ Interview with Dan Matute, Senator and prolific Author of several books on Bakweri Social and Political issues, Bobende, 7 June 2016, 63 years Old; Interview with Churchill Ewumbue.

${ }^{73}$ Interview with Chief Etina Monono; Interview with John Njanjo L.; Interview with Charles E. Endeley.

${ }^{74}$ Interview with S.M Becke; Interview with P.R.L.Ikundi; Interview with C.E.Endeley. 
and Mapanja, the Bokwai invasion of Wonya Meyo, the invasion of Wotolo by Soppo Mokongo in 1930 and the attack by Soppo Mokongo in 1930 were all fell under this category. ${ }^{75}$ However, many villages employed two or more of these techniques in their conflicts with other villages.

The armies comprised bands of warriors (wana'a wa njuma) who were all men aged between sixteen and sixty years. Women and children were not involved in the actual fighting. In most instances, women and children were taken to hill and mountain tops or to the forests for safety. Nevertheless, many elderly women stayed in the villages to provide food and other necessities to the warriors and also to serve as spies for their villages. ${ }^{76}$ It should be noted that in most of the wars, the commander of the forces (warriors) was most often than not, a member of the royal family.

Before engaging in combat, the head of the village and other notables consulted the village ancestral shrine liyai la mbando, poured libations and solicited for help from their ancestors in the battle. The warriors were then dressed in dried palm leaves and animal skin, their bodies painted black and white with charcoal and wood ash. The village nganga (native doctor/spiritualist) was also part of these preparations as he had to make some incantations. $\mathrm{He}$ also made special lotions and charms to protect the warriors in battle. ${ }^{77}$ Each warrior also had their personal lotions and charms for protection in battle.

The weapons of the Upper Bakweri warriors consisted of Dane guns (mokomba), cutlasses (njambi), knives (mawendi), clubs (weye), bows (likossi) and arrows (mowanja) mostly made from bamboos and spearheads. The latter was of three kinds: liongo with two bards at the peak; jangu with many barbs and leaf shaped, zolo with no barbs. In major wars, trenches (evanja) were also dug to serve as traps for the enemy. ${ }^{78}$

Prior to a war, the warriors were alerted from their homes by the village drummer ${ }^{79}$ or the blowing of war horns that sent a message of war across the entire village to the understanding of all. In the event of war, the tune used by the UBL drummers echoed the war song thus as sung by wana wa njuma (warriors) "Jimbi, kombi, esewa etongi, etongi ndi maongo, Wana'a wa njuma esaweya, evonda njuma, emuka, etaneya nd'o mafafy" "80 meaning: The drum is sounding, the horn is blowing, and they are sounding but trouble. Warriors listen, the time of war is here. We should all meet at the village square.

The war strategy was to either capture the head of the opposing village, or head of the warriors and behead him. The conquered village was set ablaze including their crops and animal farms. Women from the conquered village were then taken captive to serve as leverage for future negotiations. Wars in UBL were guided by generally accepted norms and principles. These included the exclusion of women and children from active combat. They were also not to be tortured even when they were captured. Rape and other indecent acts on women and other prisoners of war (captives) were strictly prohibited. Captives were supposed to be given food and proper health care. Sacred shrines and village artifacts likewise, were not to be destroyed. Parties which were found to have violated these principles were heavily punished during adjudication by a third party. ${ }^{81}$

\section{Conclusion}

Although, traditional authority in Upper Bakweri Land was well constituted under the sang'a mboa and his wambaki wa mboa which took care of the administrative, judiciary and security aspects of each village inter-village wars developed between them. The wars that were fought in Upper Bakweri Land exemplified expansionist ideas especially in Soppo Mokongo under their leader Sako Ewumbua and in Gbea led by kuva Likenye. The need for

${ }^{75}$ Interview with Chief Etina Monono; Interview with Charles E. Endeley.

${ }^{77}$ Interview with Chief Etina Monono; John Njanjo L.; Interview with Charles E. Endeley.

${ }^{77}$ Idem.

${ }^{78}$ Interview with Dan Matute; Interview with Churchill Monono; Interview with Smith Molua Becke; Interview with Sam Efufa Becke.

${ }^{79}$ Idem.

${ }^{80}$ Interview with Dan L. Matute; Interview with Charles E.Endeley.

${ }^{81}$ Interviews with Dan L. Matute; Interview with Churchill Monono; Interview with smith Molua Becke; Interview with Sam Efufa Becke. 
territorial aggrandizement fermented by their desire to control the other villages, led them to invade weaker and smaller villages like Bonakanda, Wonjia, Molyko, and Wonganga in a bid to enhance their prowess and prestige. One of the ways to achieve this was to build alliances in other to display their strength. The result was the formation of two alliances: the Soppo Alliance and the Gbea Alliance. The wars therefore led to division in UBL that produced two divergent camps, each struggling to exert power in the area. The formation of these two alliances embolden their surrogate villages to invade others as they were certain of the support of either Soppo Mokongo or Gbea using economic and socio-cultural excuses. In some cases the search for farming and hunting land, the quests for natural resources like firewood, the ambition to control the middleman trade routes and the desire to acquire captives were all grounds that triggered wars in UBL. In other situations, wars were highlighted by social concerns. Forced marriages and wrestling debacles were top on the list of the foundation of social wars in UBL. It is important to mention the fact that most of the wars were gingered by indigenous factors.

Apart from the causes and manifestations of wars in UBL, the paper also discusses the nature of the wars. The paper posits that there were two types of wars in UBL; just and unjust wars. Basically, just warss were those which arose as a result of a village retaliating to an act perpetuated by an aggressor. The 1880s Soppo Wonganga and Soppo Woteke attack on Soppo Likoko, the 1890 Boando conflict with Molende, the 1890 Gbea attack on Maumu, the 1891-94 Bokwaongo attack on Mapanja, the 1897-1900 Soppo Mokongo war with Molyko, the 18981900 Bokwai attack on Wonya Meyo, and the 1930 Soppo Mokongo attack on Bokwaongo were all considered as 'just wars.' However, the 'unjust wars' were those which arose as consequence of attempts for territorial conquest of a village by another village. Thus, the expansionary wars of mwe Ekpa of the 1880s, the 1884-85 Soppo Wonganga attack on Mapanja, the 1889 Bonakanda attack on Bova, the 1890 war between Bova and Wonjia, the Bonakanda invasion of Maumu in 1891, and the 1930 Soppo Mokongo attack on Wotolo were all considered as 'unjust wars' as they were aimed at fostering the fame and prestige of the aggressor villages. Again, the paper came up with four dimensions of combat used in the area; ritualized combats on traditional battle grounds, ambushes, surprised attacks and outward declaration of njuma (war). An examination of the type of weapons used showed that the warriors of UBL used Dane guns, cutlasses, knives, clubs, bows and arrows during fighting.

\section{SOURCES CONSULTED}

\section{Interviews}

[1] Becke, Rebecca Motomby. Traditional Leader of the Great Soppo Women, Great Soppo, 6 July, 2016, 65 years Old.

[2] Becke, Sam Efufa. Notable, Great Soppo, 6 May, 2016, 86 years Old.

[3] Becke, Smith Molua. Notable of Great Soppo, Former Municipal Administrator of the Buea Rural Council, Former Chairman of the Great Soppo Traditional Council and Council of Elders, Great Soppo, 6 July, 2016, 76 years Old.

[4] Efange, Isaac. Notable of Soppo Wonganga, Molyko, 17 May, 2016, 83 years Old.

[5] Ekwa, Itue Hans. Elder, Great Soppo, 16 May, 2016, 91 years Old.

[6] Endeley, Charles Efungani. Retired Senior Administrator with the CDC, Son and Confidant of the late Nakuve S.M.L. Endeley and the Crowned Prince of Buea, Buea Town, 31 August, 2016, 63 years Old.

[7] Evakise, Monangai mo. Notable, Bokwaongo, 21 June, 2016, 86 years Old.

[8] Ewome, Manga Ferdinand. Notable and Retired Administrator, Bokova, 31 August, 2016, 82 years Old.

[9] Ewome, Mwambo Paul. Notable, Bonakanda, 30 April, 2016, 73 years Old.

[10] Ewome, Njie Mosoke. Notable of Wokulu, Wokulu, 23 May, 2016, 86 years Old.

[11] Fike, Mbua Efeme Dan. Member of the family of King Makers of Soppo Mokongo, Great Soppo, 25 June, 2016,53 years Old.

[12] Ikome, Samuel. Notable, Great Soppo, 17 May, 2016, 63 years Old.

[13] Ikundi, Peter Rey Lyonga. Notable of Buea Town, Former Municipal Administrator of the Buea Rural Council and Former Secretary and Vice Chairman of the Buea Town Traditional Council, Buea Town, 21 August 2016, 73 years Old.

[14] Luma, John Njanjo. Traditional Griot and Member of the Great Soppo Traditional Council, Great Soppo, 7 June, 2016, 45 years Old.

[15] Matute, Dan Lyonga. Senator for Limbe and prolific Author of several books on Bakweri Social and Political issues, Bobende-Limbe, 7 June, 2016, 63 years Old.

[16] Molombe, Ewoma. Notable, Bonakanda, 22 June, 2016, 83 years Old.

[17] His Royal Highness Chief Monono, Etina. Chief of Great Soppo, Great Soppo, 16 July, 2016, 61 years Old.

[18] Monono, Churhill Ewumbua. Elite of Great Soppo, Great Soppo, 10 July, 2016, 56 years Old.

[19] Monono, John Matanga. Member of the Council of Elders, Great Soppo, 16 July, 2016, 55 years Old. 


\section{Archival Materials}

[1] NAB, Ag.10. File No. EP.11372A. W.M Bridges D.O's Intelligence Report on Bakweri of Victoria Division, Cameroon Province.

\section{Thesis/Dissertations}

[1] Mbake, Samuel Njie. "Traditional Authority among the Bakweri: A Historical Survey from Pre- colonial Times." D.E.S Dissertation, University of Yaoundé, 1975.

[2] Fru, Cletus Forba. "Urbanisation in Buea: Process and Problems (1960-1999)." Master of Science Thesis, University of Buea, 2004.

\section{Books/Book Chapter}

[1] Ardener, Edwin. Coastal Bantu of the Cameroons: An Ethnographic Survey of Africa. London: International African Institute, 1956.

[2] Ardener, Edwin. Kingdom on Mount Cameroon: Studies in the History of the Cameroon Coast, 1500-1970. Oxford: Berghahn Books, 1996.

[3] Matute, Dan Lyonga. How did Buea Originate? Guinness Mount Cameroon Race Special, $1985 . \quad$ Buea: GUINNESS, 1985.

[4] Matute, Dan Lyonga. The Socio-Cultural Legacies of the Bakweris of Cameroon. Yaoundé: CEPER, 1988.

[5] Monono, Churchill Ewumbue. Buea, Capital of the Cameroons: Symbol of the Nation and of Reunification. Buea: CEREDDA, 2015.

[6] Odoememe, Akachi. "Warfare and Diplomacy in Pre-Colonial West Africa" in Perspectives in African History, Edited by Ogbogbo, C.B.N. Ibadan: Bookwright Publishers, 2011.

[7] Smith, Robert S. Warfare and Diplomacy in Pre-Colonial West Africa: Studies in African History 15. London: Methuen \& Co. Ltd, 1976. 